\title{
Uptake of resistant varieties and integrated management packages for bean root rot disease in western Uganda
}

\author{
L. Nasirumbi Sanya ${ }^{1,2}$, M.A. Ugen ${ }^{2}$, F. Opio ${ }^{3}$, J.I. Mugagga ${ }^{2}$ and A. Namayanja ${ }^{2}$ \\ ${ }^{1}$ Mukono Zonal Agricultural Research and Development Institute (Mukono ZARDI), P. O. Box 164, \\ Mukono, Uganda \\ ${ }^{2}$ National Crops Resources Research Institute (NaCRRI), P. O. Box 7084, Kampala, Uganda \\ ${ }^{3}$ Association for Strengthening Agricultural Research in Eastern and Central Africa (ASARECA), \\ P. O. Box 765, Entebbe, Uganda
}

Author for correspondence: losirasfm@gmail.com, nasirumbil@yahoo.com

\begin{abstract}
The common dry bean (Phaseolus vulgaris L.) is the most widely grown food legume in Uganda, however, its production in western Uganda has been threatened by the bean root rot diseases. Resistant varieties and integrated soil and crop management package for the bean root rot disease, developed by the National Beans Research Programme, were promoted from 2003 to 2007 in Bushenyi and Kisoro Districts that were most susceptible to this disease. This study was conducted to assess the level of uptake of technologies and practices promoted in the target area, and factors influencing the decision to adopt. Data were collected using a semi-structured questionnaire that was administered to 160 purposively selected bean farmers. The Poisson regression model was used to determine the factors influencing the number of technologies and practices used. The study revealed that majority $(95.0 \%)$ of the bean farmers had adopted at least one of the improved bean varieties promoted. The results further show that NABE 12C, NABE 13 and NABE 14 were the most preferred improved varieties. Preference was mainly attributed to high yield, palatability and short cooking time. Use of improved and resistant varieties $(95.0 \%)$, sowing of one seed per hole $\mathbf{7 2 . 5 \%}$ ) and Farm Yard Manure $\mathbf{( 7 1 . 3 \%}$ ) were the most commonly used in management of the bean root rot disease. Analysis of the sequential combination of technologies adopted reveal that most farmers in Kisoro district used improved varieties + Farm Yard Manure + Row planting + One seed per hole; while the farmers in Bushenyi mainly used a combination of improved varieties + Farm Yard Manure +Crop Rotation + One seed per hole. Poisson results indicated that adoption was significantly and positively influenced by access to bean information, number of times a farmer was trained, participation in farmer to farmer seed loan scheme, record management and the price of improved varieties. Age of household head had a negative influence and significantly reduced the expected number of technologies and practices used in the management of BRR disease by $20 \%$. To sustain the use of bean root rot management technologies and practices, there is need to support establishment of community-based seed production systems which have already shown evidence of success in other areas and crops to ensure availability of sufficient
\end{abstract}


quantities of seed and access to resistant varieties; support rural enterprises which provide inputs; and ensure farmers' continued access to information though use of different channels and media.

Key word: Adoption, Farm Yard Manure, Phaseolus vulgaris

\section{Introduction}

The common dry bean (Phaseolus vulgaris L.) is the most important legume crop grown and eaten in Uganda. The crop is a cheap source of protein for almost 30 million people in Uganda, providing $45 \%$ of the total human dietary protein (Mauyo et al., 2007), in both the rural and urban areas. In addition, the crop is important for income generation for the smallholder farmers in rural areas, particularly the women. Additionally, it is a valuable source of calories, micronutrients (zinc and iron), vitamin B complex, folic acid, complex carbohydrates and other essential minerals (Kornegay et al., 1996; Opio et al., 2001). Bean offers very unique opportunities in Uganda to address the deteriorating food security situation and contribute to poverty alleviation among the rural communities and the urban poor by providing both food and nutrition security and income.

Till the early 1990s, western Uganda was the greatest producer of beans accounting for over $30 \%$ of the beans produced in the country (MAAIF, 1992). Unfortunately, there was a remarkable decline in beans production in this region and by 1995 , production had reduced to less than 20\% (MAAIF, 1997). This decline was mostly attributed to high incidence and severity of bean root rot (BRR) disease that had widely spread, causing up to $100 \%$ yield losses (Opio et al., 2000; Mukankusi, 2007). Bean root rot is caused by a complex of pathogens, but in southwest Uganda, Fusarium solani f.sp. and phaseoli are the most prevalent (Mukankusi, 2007). Bean root rot is caused by prevailing environmental and soil conditions that favour infection, as well as when beans are grown continuously in the same field or crop rotation is inadequate (Abawi and Corrales, 1990).

In the early 2000 , the disease had reached epidemic level with $100 \%$ yield loss during severe attack in Bushenyi and Kisoro districts causing an outcry for control measures to the BRR disease. All local varieties previously grown in the area were susceptible to the disease. Therefore, there was urgent need to avail BRR resistant varieties and other management practices to the affected farming communities. Farmers in the area identified, resistant bean varieties, improved soil fertility and cultural practices as priority approaches to emphasize in handling the BRR problems.

This study was therefore carried out to assess the uptake level of the improved technologies and practices disseminated between 2003 and 2007 under the project titled "Improving Food Security in South Western Uganda through Transfer and Promotion of Resistant Varieties and Integrated Management Packages for Bean Root Rot Disease”, supported by Maendeleo Agricultural Technology Transfer Fund (MATTF) and in partnership with Kachwekano Agricultural Research and Development Institute, District Local Governments, Africa 2000 Network (A2N), Ankole Private Sector Promotional Centre (APROCEL), District Farmers 
Associations and farmer groups in the two districts.

The specific objectives were to: (a) assess the level of adoption of improved and BRR resistant varieties and integrated soil and crop management practices, (b) determine the factors influencing the number of technologies adopted in management of BRR disease, and (c) determine the changes in production, social and economic aspects as a result of using improved and resistant varieties and management practices.

\section{Materials and methods}

\section{Study area and sampling procedure}

The study was carried out in the two MATTF project implementing districts of Bushenyi and Kisoro, which were purposively selected. Only the participating two sub-counties in each district and three parishes per sub-county were purposively selected. A list of farmers who participated in the project was obtained and this formed the sampling frame. A total of 160 households were randomly selected and interviewed. At household level, deliberate effort was taken to interview the farmer that directly participated in the project, whether household heads or spouses in maleheaded households. Where husband, and wife were involved, both were interviewed as one family.

\section{Data collection}

Data used in the study were obtained primarily from a household survey that targeted project participating households. A semi-structured questionnaire was used to collect both quantitative and qualitative data. It was pilot tested before the actual survey and the results generated were used to modify the questionnaire. Data were collected on BRR disease, resistant varieties and control management package adopted and factors including the adoption choice. Additional data were collected on the changes in bean yields, consumption, marketable surplus and household income as well as farmers' participation in the different promotional methods and their own assessment of the contribution of these methods used in enhancing uptake. The study employed a quantitative research design using a crosssectional descriptive survey.

\section{Data processing and analysis}

Data were checked and open ended questions were coded before data entry. Data were analysed using the Statistical Package for Social Scientists (SPSS) Version 16 and STATA Version 12.1. Descriptive (mainly means, frequencies, percentages) and inferential (t-test, chi square, paired t-tests and regression analysis) statistics were used to analyse the data. The hypothesis that MATTF project increased the number of technologies and practices used in bean production as a response to BRR disease was tested.

The Poisson regression model was used to determine the factors influencing the number of technologies and practices adopted in the management of BRR disease. The model was chosen over others because (a) it takes into account the nonnegative and discrete nature of the number of technologies used, (b) it accounts for the assumption of equality of the variance and conditional mean. Following previous studies (Cameron and Trivedi, 1999; Greene, 2008), the expected number of technologies used per period is given as:

$$
E\left(y_{i} \mid x_{i}\right)=\operatorname{var}\left[y_{i} \mid x_{i}\right]=\lambda_{i}=\exp \left(\alpha+X^{\prime} \beta\right)
$$


4

for $\mathrm{i}=1,2, \ldots, \mathrm{n}$.

Where $\mathrm{y}$ is number of technologies used, $\alpha$ and $\beta$ are coefficients, and $X$ is a vector of covariates defined as:

num_technologies_adopted =

f(keep_records, group_member,

get_info_bean, no_times, sex_hh, Inage_hh, educhh, hhsize, Inlandbeans, offfarm_work, important, part_sdloan, pxnow_imp) $+e$

Where the dependent variable numtechnologies is equal to the count of technologies used by a farmer in bean production; while the rest of the variables are as earlier defined. Ten technologies were considered as part of the dependent variable, namely: improved bean varieties, use of farm yard manure, green manure, inorganic fertiliser use, crop rotation, timely planting, planting on raised beds or ridges, row planting, planting one seed per hole, mono-cropping. It was hypothesized that farmer's decision to apply the management package for BRR disease at any time was influenced by factors related to socio-economic characteristics, institutional and market factors. The variables expected to influence adoption of the BRR management package were largely derived from literature.

\section{Results}

\section{Household socio-economic characteristics}

\section{Sex of respondent}

Results show that most of the respondents were female farmers $(67 \%)$ across the districts, and the proportion of female farmers was also higher in both
(1) Bushenyi (70\%) and Kisoro (64\%) (Table $1)$. The statistics also show that the proportion of male headed households is greater $(83.75 \%)$ than that of female headed. Male headed households still formed the majority in Kisoro (85.0\%) and Bushenyi (82.5\%) districts and thus, the difference in household headship between the two districts was not significant.

\section{Age and education level}

On average, farmers interviewed were 46.73 years of age, with a range of 20 80 years (Table 1 ). Though not statistically different, the farmers in Kisoro were slightly older (47.1 years) than those in Bushenyi (46.3 years). In terms of education, the result indicates that farmers attained on average seven years of education/schooling which is an equivalent of attaining primary leaving Examination Certificate (PLE). The farmers in Kisoro had a statistically significantly higher mean score on education ( 8 years) than those from Bushenyi (6 year).

\section{Household size and labour source}

The average household size was seven family members, with a minimum of 2 and a maximum of 16 members (Table 1). The households in Kisoro reported significantly more household members (7.8) relative to Bushenyi District (6.7). On average, five members were actively working on the farm across the districts. Households in Kisoro had relatively more household active members ( 5 members) working on the farm compared to Bushenyi (4 members). Family therefore, constituted the main source of labour for crop production, though about $53.8 \%$ of the farmers reported to supplement their family labour with hired labour. 
Table 1. Socio-economic characteristics of bean farmers in western Uganda

\begin{tabular}{|c|c|c|c|c|c|c|c|c|c|c|c|}
\hline \multirow[t]{2}{*}{ Characteristics } & \multicolumn{3}{|c|}{ Pooled sample } & \multicolumn{3}{|c|}{ Kisoro } & \multicolumn{3}{|c|}{ Bushenyi } & \multirow[t]{2}{*}{ t-test } & \multirow[t]{2}{*}{$P$ value } \\
\hline & $\mathrm{n}$ & Mean & $\mathrm{SD}$ & $\mathrm{n}$ & Mean & SD & $\mathrm{n}$ & Mean & SD & & \\
\hline Age of farmer (years) & 160 & 46.73 & 12.88 & 80 & 47.13 & 11.69 & 80 & 46.34 & 14.04 & 0.386 & 0.700 \\
\hline Education level (years of schooling) & 124 & 6.93 & 3.35 & 54 & 7.81 & 3.57 & 70 & 6.24 & 3.01 & 2.658 & 0.009 \\
\hline Household size & 160 & 7.33 & 2.90 & 80 & 7.86 & 3.04 & 80 & 6.79 & 2.67 & 2.375 & 0.019 \\
\hline Number of active $\mathrm{HH}$ members & 160 & 4.93 & 2.44 & 80 & 5.33 & 2.55 & 80 & 4.53 & 2.26 & 2.100 & 0.037 \\
\hline Number of persons in $\mathrm{HH}$ working on-farm & 160 & 4.76 & 2.34 & 80 & 5.10 & 2.38 & 80 & 4.43 & 2.26 & 1.838 & 0.068 \\
\hline Total land size (acres) & 160 & 3.72 & 4.28 & 80 & 2.75 & 3.47 & 80 & 4.69 & 4.78 & -2.927 & 0.004 \\
\hline Cultivable land (acres) & 160 & 2.99 & 2.80 & 80 & 2.50 & 2.88 & 80 & 3.48 & 2.64 & -2.252 & 0.026 \\
\hline Total land under crops (acres) & 160 & 2.57 & 2.34 & 80 & 2.09 & 2.19 & 80 & 3.05 & 2.40 & -2.652 & 0.009 \\
\hline Total land under beans (acres) & 160 & 0.88 & 0.79 & 80 & 0.90 & 0.86 & 80 & 0.86 & 0.73 & 0.355 & 0.723 \\
\hline Total land under improved varieties (acres) & 152 & 0.38 & 0.42 & 75 & 0.28 & 0.29 & 77 & 0.47 & 0.50 & -2.766 & 0.006 \\
\hline Average bean plot numbers & 160 & 2.92 & 1.51 & 80 & 3.42 & 1.66 & 80 & 2.41 & 1.14 & 4.446 & 0.000 \\
\hline Average plot size (acres) & 153 & 0.31 & 0.29 & 73 & 0.28 & 0.28 & 80 & 0.34 & 0.30 & -1.308 & 0.193 \\
\hline Average sesonal income (UGX) & 152 & 525662 & 485131 & 73 & 482384 & 512659 & 79 & 565653 & 457867 & -1.058 & 0.292 \\
\hline \multicolumn{12}{|c|}{ Source: Field survey data SD is Standard Deviation $\mathrm{HH}$ is Household } \\
\hline
\end{tabular}


Land allocation to crop production and average seasonal income

Bean farmers in the area owned about 1.21 ha of cultivable land, out of which 1.04 and 0.36 ha were allocated to crop production and common beans, respectively (Table 1). Out of the 0.36 ha allocated to common beans production, $43.2 \%$ was reported to be under improved varieties across the districts. In Bushenyi district, improved varieties were grown on about $54.8 \%$ of the land area allocated to beans production, compared to only $31.5 \%$ in Kisoro. In addition, farmers in Kisoro had significantly more plots planted with beans ( 3.4 plots) than Bushenyi district (2 plots). However, the average plot size was relatively greater in Bushenyi (0.14 ha) than in Kisoro district (0.11 ha) (Table 1).

The seasonal income for an average household in the sample was Uganda shillings (UGX) 525,661 equivalent to US\$ 250.31 across the two districts, with an average of UGX 482,383 (US\$229.71) and UGX 565,653 (US\$ 269.36) in Kisoro and Bushenyi, respectively. However, the difference in seasonal household between Kisoro and Bushenyi District was not significant.

\section{Livestock assets}

Most (83.75\%) households owned livestock. Goats $(60.6 \%)$, cattle $(46.3 \%)$ and chicken $(26.9 \%)$ were the main livestock types owned across the districts. Households in Bushenyi district mainly reared goats $(63.8 \%)$ and cattle $(56.3 \%)$; while those in Kisoro mainly reared goats $(57.5 \%)$ and chicken $(40.0 \%)$. It was reported by $91 \%$ of the farmers that livestock was an important household asset, particularly for crop production since it provided farm yard manure for improving soil fertility.

\section{Farmer preference for bean varieties} Majority $(85.6 \%)$ of the farmers grew both local and improved varieties (Table 2). Overall, $95.0 \%$ of the farmers had adopted at least one of the improved bean varieties promoted by the project. Whereas Owizarahenda (65.0\%) was the most popular local cultivar still grown in Kisoro district, K20 (46.9\%) formed the most popular local variety grown in Bushenyi (Table 3). NABE 12C (67.8\%) was the most preferred improved variety among the households across the districts. This variety still formed the most popular and widely adopted improved variety in Kisoro District, and was grown by all the farmers $(100 \%)$. The highest percentage $(68.8 \%)$ of the farmers in Bushenyi preferred NABE 13 (Table 3). Other improved varieties selected and grown

Table 2. Type of bean varieties grown by the two districts in western Uganda

\begin{tabular}{lccc}
\hline Type of varieties & \multicolumn{3}{c}{$\%$ of responses } \\
\cline { 2 - 4 } & $\begin{array}{c}\text { Total sample } \\
(\mathrm{n}=160)\end{array}$ & $\begin{array}{c}\text { Kisoro } \\
(\mathrm{n}=80)\end{array}$ & $\begin{array}{c}\text { Bushenyi } \\
(\mathrm{n}=80)\end{array}$ \\
\hline Both improved and local varieties & 85.6 & 93.75 & 77.5 \\
Only improved varieties & 10.0 & 0 & 20.0 \\
Only local varieties & 4.4 & 6.25 & 2.5 \\
\hline
\end{tabular}

Source: Field survey data 


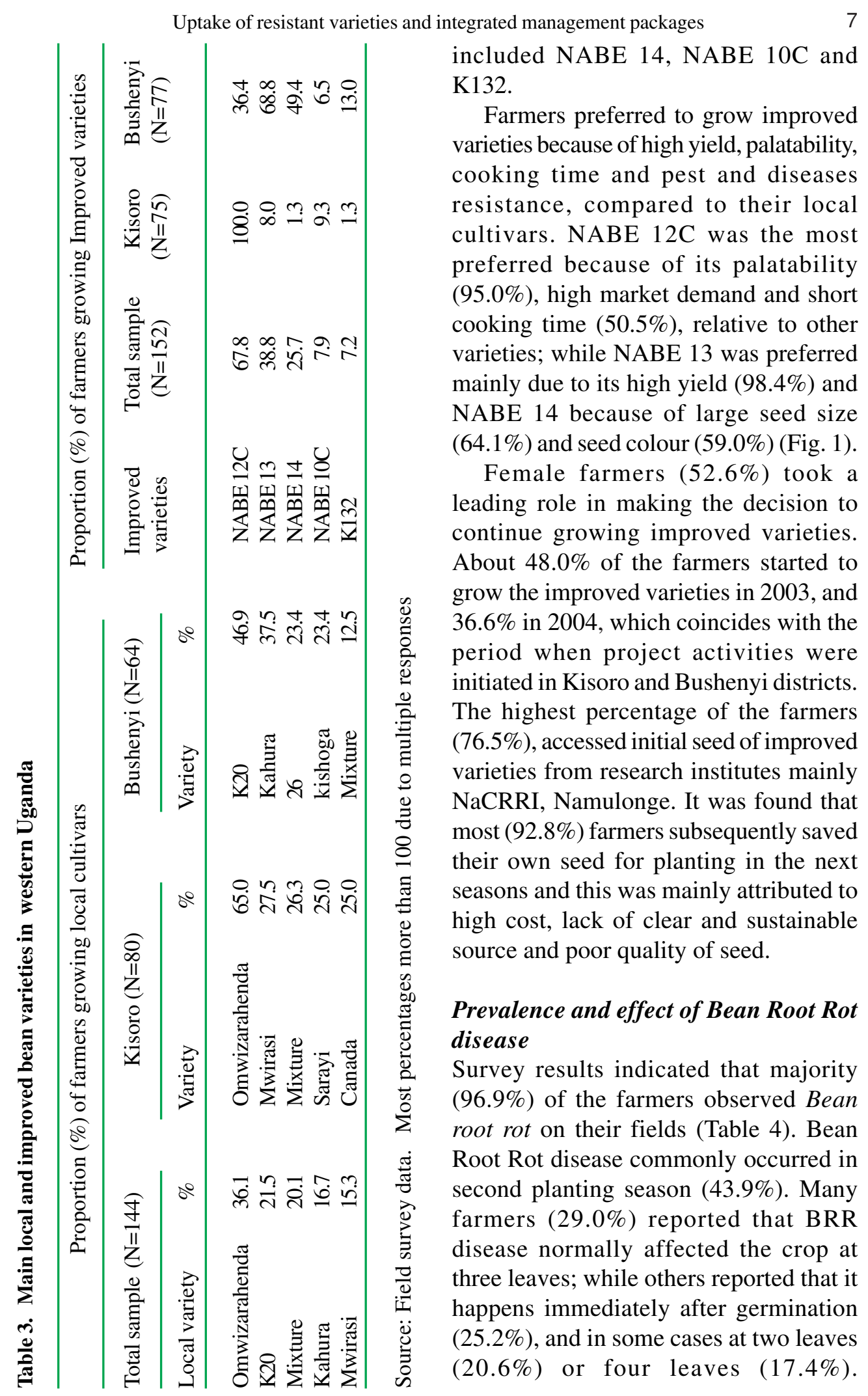




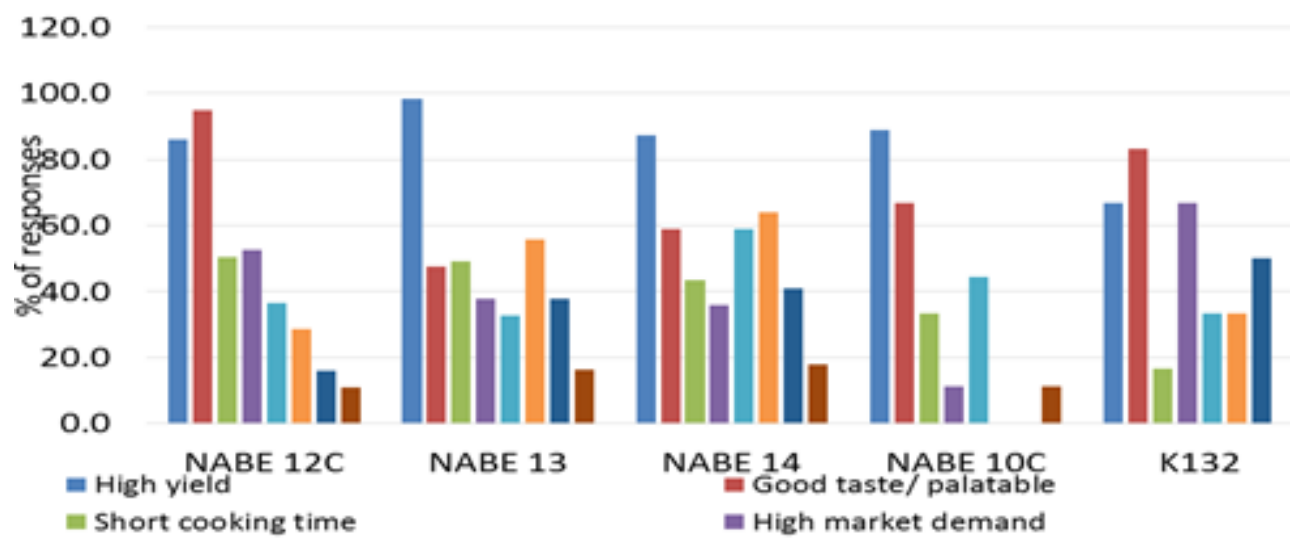

Figure 1. Main attributes influencing farmers' preferences/choice of selected improved bean varieties in western Uganda.

Table 4. Observed change in prevalence of BRR disease with project activities in western Uganda

\begin{tabular}{llcc}
\hline Variable & $\begin{array}{l}\text { Observed/ } \\
\text { response }\end{array}$ & Frequency & $\begin{array}{c}\% \\
\text { of responses }\end{array}$ \\
\hline If farmer observed bean root rot on & Yes & 155 & 96.9 \\
the farm (N=160) & No & 5 & 2.5 \\
Main symptoms of the disease & Yellowing of leaves & 157 & 98.7 \\
(N=159)* & Drying of roots & 95 & 59.7 \\
How BRR affected bean yield & Reduced yield & 81 & 51.3 \\
(N=158) & No yield at all & 72 & 45.6 \\
& No effect on yield & 5 & 3.2 \\
BRR Disease effect over the last & Reduced & 145 & 91.2 \\
3 years (N=159) & Increased & 10 & 6.3 \\
& No change & 4 & 2.5 \\
\hline
\end{tabular}

Source: Field survey data. * Multiple response so the percentage total exceed 100\%

Yellowing of the leaves (98.7\%) and drying of roots $(59.7 \%)$ were reported as the main observable symptoms used by farmers to identify the BRR disease in the field. It was reported by $51.3 \%$ of the farmers that the BRR disease reduced yields; while $45.6 \%$ farmers realised no yields at all during BRR attack. Majority
(91.2\%) of the farmers reported that the effect of BRR disease had relatively reduced over a period of 3 years since the inception of the project, Table 4. All the farmers that reported a no change or increase in the effect of BRR disease were among those still growing local varieties. 
Uptake of resistant varieties and integrated management packages

Farmers' adoption of technologies and practices for management of BRR disease

\section{Existing technologies and practices} Majority $(95.6 \%)$ of the farmers knew some technologies and practices that control BRR. Use of improved and resistant varieties $(95.0 \%)$, planting the recommended one seed per hole $(72.5 \%)$ and use of farm yard manure (FYM) (71.3\%) were the most common technologies and practices used in control and management of the BRR disease (Fig. 2). Other soil based practices included use of green manure and inorganic fertilisers, crop rotation, row planting, mono-cropping and planting on raised beds or ridges and timely planting. Improved varieties (93.8\%) and recommended seed rate (87.5\%) were the most used practices in Kisoro district compared to improved varieties and FYM in Bushenyi District. Before the project, $60 \%$ of the farmers did not have control measures to BRR. Only $20.4 \%$ reported to have previously used crop rotation to reduce on the spread of the disease. Farmers reported that the information on control and management practices was mainly obtained from research institutes (mainly at Namulonge) and extension officers within their localities.

\section{Choice of technologies and practice combinations (level of adoption)}

Results indicate that $99.4 \%$ of the farmers had adopted at least one of the BRR disease control and management technologies or practices. Further analysis of the sequence of combinations adopted (level of adoption) of control and management technologies or practices) generated up to 73 different combinations used by farmers in the control and management of BRR Disease. The highest percentage of farmers used improved varieties + Farm Yard Manure + Row/line planting + One seed per hole (Table 5). This same combination was the most widely adopted/used by farmers in Kisoro District. However, farmers in Bushenyi mainly use combination of improved varieties + Farm Yard Manure + Crop Rotation + One seed per hole.

Generally, it was reported that use of resistant varieties and soil improvement practices were the most effective in managing and controlling the BRR disease. About $70.0 \%$ of the farmers

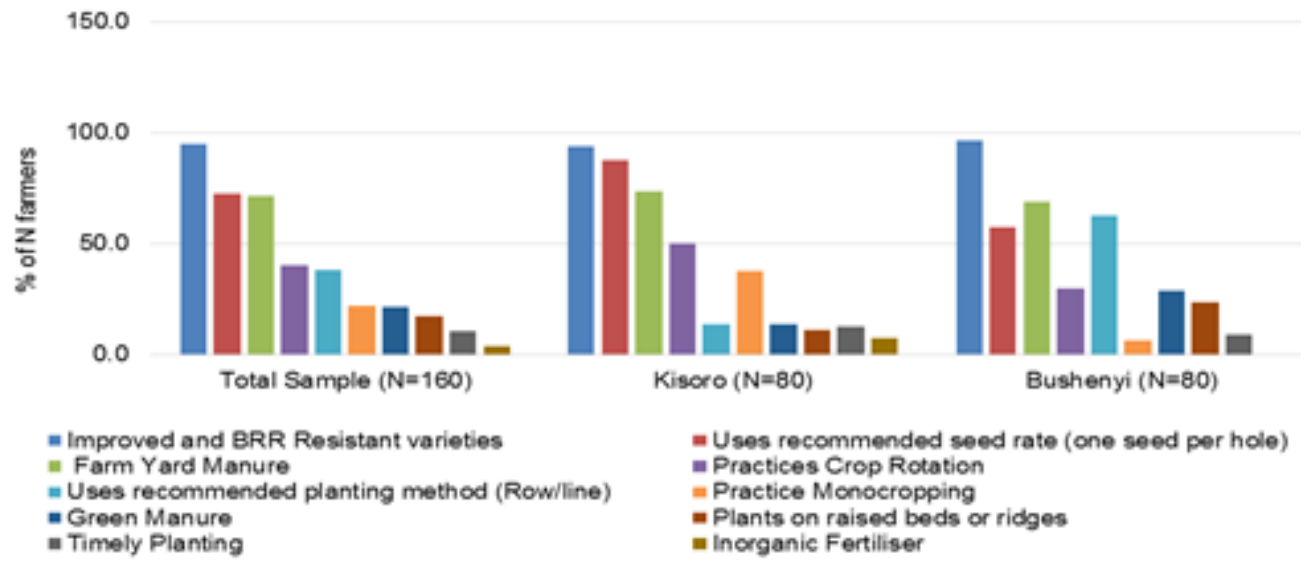

Figure 2. Proportion of farmers using the recommended technologies and practices for BRR management and Control in western Uganda. 


\begin{tabular}{|c|c|c|c|c|c|c|c|c|c|c|c|c|c|c|}
\hline \multirow[t]{2}{*}{$\mathrm{S} / \mathrm{N}$} & \multicolumn{10}{|c|}{ Order of sequence } & \multirow[t]{2}{*}{ Combination } & \multicolumn{3}{|c|}{$\%$ of responses } \\
\hline & $\begin{array}{l}\text { Improved } \\
\text { and BRR } \\
\text { resistant } \\
\text { varieties }\end{array}$ & $\begin{array}{l}\text { Farm } \\
\text { Yard } \\
\text { Manure }\end{array}$ & $\begin{array}{l}\text { Green } \\
\text { manure }\end{array}$ & $\begin{array}{l}\text { Inorganic } \\
\text { fertiliser }\end{array}$ & $\begin{array}{l}\text { Crop } \\
\text { rotation }\end{array}$ & $\begin{array}{l}\text { Timely } \\
\text { planting }\end{array}$ & $\begin{array}{l}\text { Plants } \\
\text { on } \\
\text { raised } \\
\text { beds or } \\
\text { ridges }\end{array}$ & $\begin{array}{l}\text { Uses } \\
\text { reco- } \\
\text { mmended } \\
\text { planting } \\
\text { method } \\
\text { (row/line) }\end{array}$ & $\begin{array}{l}\text { Uses } \\
\text { reco- } \\
\text { mmended } \\
\text { seed rate } \\
\text { (one seed } \\
\text { per hole) }\end{array}$ & $\begin{array}{l}\text { Practice } \\
\text { mono- } \\
\text { cropping }\end{array}$ & & $\begin{array}{l}\text { Total } \\
\text { Sample }\end{array}$ & Bushenyi & Kisoro \\
\hline 1 & $\mathrm{Y}$ & $\mathrm{Y}$ & $\mathrm{N}$ & $\mathrm{N}$ & $\mathrm{N}$ & $\mathrm{N}$ & $\mathrm{N}$ & $\mathrm{Y}$ & $\mathrm{Y}$ & $\mathrm{N}$ & $\begin{array}{l}\text { Improved varieties + Farm } \\
\text { Yard Manure+Row/line } \\
\text { planting+One seed per hole }\end{array}$ & 7.5 & 12.5 & 2.5 \\
\hline 2 & $\mathrm{Y}$ & $\mathrm{Y}$ & $\mathrm{N}$ & $\mathrm{N}$ & $\mathrm{Y}$ & $\mathrm{N}$ & $\mathrm{N}$ & $\mathrm{N}$ & $\mathrm{Y}$ & $\mathrm{N}$ & $\begin{array}{l}\text { Improved varieties + Farm } \\
\text { Yard Manure+Crop Rotation } \\
\text { +One seed per hole }\end{array}$ & 5.6 & 1.3 & 10.0 \\
\hline 3 & $\mathrm{Y}$ & $\mathrm{Y}$ & $\mathrm{N}$ & $\mathrm{N}$ & $\mathrm{Y}$ & $\mathrm{N}$ & $\mathrm{N}$ & $\mathrm{N}$ & $\mathrm{N}$ & $\mathrm{N}$ & $\begin{array}{l}\text { Improved varieties + Farm } \\
\text { Yard Manure+Crop Rotation }\end{array}$ & 5.6 & 5.0 & 6.3 \\
\hline 4 & $\mathrm{Y}$ & $\mathrm{N}$ & $\mathrm{N}$ & $\mathrm{N}$ & $\mathrm{N}$ & $\mathrm{N}$ & $\mathrm{N}$ & $\mathrm{N}$ & $\mathrm{Y}$ & $\mathrm{N}$ & $\begin{array}{l}\text { Improved varieties+One seed } \\
\text { per hole }\end{array}$ & 5.0 & 2.5 & 7.5 \\
\hline 5 & $\mathrm{Y}$ & $\mathrm{Y}$ & $\mathrm{N}$ & $\mathrm{N}$ & $\mathrm{Y}$ & $\mathrm{N}$ & $\mathrm{N}$ & $\mathrm{Y}$ & $\mathrm{Y}$ & $\mathrm{N}$ & $\begin{array}{l}\text { Improved varieties + Farm } \\
\text { Yard Manure+Crop Rotation+ } \\
\text { Row/line planting+One seed } \\
\text { per hole }\end{array}$ & 3.8 & 6.3 & 1.3 \\
\hline 6 & $\mathrm{Y}$ & $\mathrm{Y}$ & $\mathrm{N}$ & $\mathrm{N}$ & $\mathrm{N}$ & $\mathrm{N}$ & $\mathrm{N}$ & $\mathrm{N}$ & $\mathrm{Y}$ & $\mathrm{Y}$ & $\begin{array}{l}\text { Improved varieties + Farm } \\
\text { Yard Manure+One seed per } \\
\text { hole+ monocropping }\end{array}$ & 3.1 & 0.0 & 6.3 \\
\hline
\end{tabular}


Table 5. Contd.

\begin{tabular}{|c|c|c|c|c|c|c|c|c|c|c|c|c|c|c|}
\hline \multirow[t]{2}{*}{$\mathrm{S} / \mathrm{N}$} & \multicolumn{10}{|c|}{ Order of sequence } & \multirow[t]{2}{*}{ Combination } & \multicolumn{3}{|c|}{$\%$ of responses } \\
\hline & $\begin{array}{l}\text { Improved } \\
\text { and BRR } \\
\text { resistant } \\
\text { varieties }\end{array}$ & $\begin{array}{l}\text { Farm } \\
\text { Yard } \\
\text { Manure }\end{array}$ & $\begin{array}{l}\text { Green } \\
\text { manure }\end{array}$ & $\begin{array}{l}\text { Inorganic } \\
\text { fertiliser }\end{array}$ & $\begin{array}{l}\text { Crop } \\
\text { rotation }\end{array}$ & $\begin{array}{r}\text { Timely } \\
\text { planting }\end{array}$ & $\begin{array}{l}\text { Plants } \\
\text { on } \\
\text { raised } \\
\text { beds or } \\
\text { ridges }\end{array}$ & $\begin{array}{l}\text { Uses } \\
\text { reco- } \\
\text { mmended } \\
\text { planting } \\
\text { method } \\
\text { (row/line) }\end{array}$ & $\begin{array}{l}\text { Uses } \\
\text { reco- } \\
\text { mmended } \\
\text { seed rate } \\
\text { (one seed } \\
\text { per hole) }\end{array}$ & $\begin{array}{l}\text { Practice } \\
\text { mono- } \\
\text { cropping }\end{array}$ & & $\begin{array}{l}\text { Total } \\
\text { Sample }\end{array}$ & Bushenyi & Kisoro \\
\hline 7 & $\mathrm{Y}$ & $\mathrm{Y}$ & $\mathrm{Y}$ & $\mathrm{N}$ & $\mathrm{N}$ & $\mathrm{N}$ & Y & Y & $\mathrm{Y}$ & $\mathrm{N}$ & $\begin{array}{l}\text { Improved varieties + Farm } \\
\text { Yard Manure+Green manure } \\
\text { +Raised beds/ridges+Row/ } \\
\text { line planting+ One seed per } \\
\text { hole }\end{array}$ & 2.5 & 5.0 & 0.0 \\
\hline 8 & $\mathrm{Y}$ & $\mathrm{Y}$ & $\mathrm{N}$ & $\mathrm{N}$ & $\mathrm{Y}$ & $\mathrm{N}$ & $\mathrm{N}$ & $\mathrm{Y}$ & $\mathrm{Y}$ & $\mathrm{Y}$ & $\begin{array}{l}\text { Improved varieties + Farm } \\
\text { Yard Manure+Crop Rotation } \\
\text { +Row/line planting+One seed } \\
\text { per hole+Monocropping }\end{array}$ & 2.5 & 2.5 & 2.5 \\
\hline 9 & $\mathrm{Y}$ & $\mathrm{Y}$ & $\mathrm{N}$ & $\mathrm{N}$ & $\mathrm{Y}$ & $\mathrm{N}$ & $\mathrm{N}$ & $\mathrm{N}$ & $\mathrm{Y}$ & $\mathrm{Y}$ & $\begin{array}{l}\text { Improved varieties + Farm } \\
\text { Yard Manure+Crop rotation } \\
\text { +One seed per hole+ } \\
\text { Monocropping }\end{array}$ & 2.5 & 0.0 & 5.0 \\
\hline 10 & $\mathrm{Y}$ & $\mathrm{Y}$ & $\mathrm{N}$ & $\mathrm{N}$ & $\mathrm{N}$ & $\mathrm{N}$ & $\mathrm{N}$ & $\mathrm{N}$ & $\mathrm{Y}$ & $\mathrm{N}$ & $\begin{array}{l}\text { Improved varieties + Farm } \\
\text { Yard Manure+One seed per } \\
\text { hole }\end{array}$ & 2.5 & 0.0 & 5.0 \\
\hline
\end{tabular}


reported that a combination of Farm Yard Manure (FYM and improved varieties was the best performing in management the disease. Choice of FYM was mainly attributed to its perceived usefulness in improving soil fertility $(55 \%)$, control of the diseases $(21.6 \%)$ and availability (17.1\%); while improved varieties were mainly preferred due to their tolerance to the BRR disease $(81.2 \%)$ that resulted into high yield and the ease of the practice (16.8\%). However, inorganic fertilisers and green manure were the least adopted practices among the soil amendments options and this was largely attributed to their unavailability and high cost (78.8\%).

Therefore, majority $(85.2 \%)$ of the farmers recommended use of farm yard manure and resistant varieties as the best combination for wide dissemination. Farmers further suggested that dissemination of these practices and technologies can be enhanced through farmer trainings, use of radio, and institutions like churches, farmer groups and schools. Promoting of improved and resistant varieties through the farmer to farmer seed loan and community based seed production and supply systems were also suggested as best ways to increasing farmers access to improved seeds. However, farmers cautioned that this should be coupled with adequate and regular monitoring to track the outcomes and impact on the spread of the disease as well as food and income security.

\section{Factors influencing BRR management package}

The Poisson regression model was used to identify the factors associated with the number of resistant varieties and integrated management package adopted for control of BRR disease (Table 6). Several variables affect the expected number of technologies and practices (package) a farmer uses in management of BRR disease. The results from the model show that the significant determinants of adoption of resistant varieties and integrated management package for the disease included age of household head, access to information about beans, number of times a farmer was trained, participation in farmer to farmer seed loan, record management and the price of improved varieties.

Age of household head was found to significantly reduce the expected number of technologies and practices used in the of BRR disease by $20 \%$. As hypothesized, access to information had a significantly positive relationship with adoption of the management technologies and practices for BRR. All other things being equal, the probability of adoption of BRR management package increased with access to information (by 16\%) about beans and BRR disease. Also, the number of times a farmer was trained increased the number of technologies used by $6 \%$. As expected, farmer participation in the seed loan scheme increased the number of technologies and practices used in the control of BRR disease by $10.7 \%$.

\section{Transfer and promotion of resistant varieties and management package}

The transfer and promotion of resistant varieties and integrated management practices for BRR was achieved using majorly four dissemination methods and approaches viz; demonstrations, farmer field schools (FFS) (only in Kisoro district), farmer to farmer seed loans and farmer training. Whereas most farmers participated in more than one method, majority of the farmers participated in demonstrations $(89.1 \%)$. This was followed by trainings, seed loans and FFS 
Uptake of resistant varieties and integrated management packages

Table 6. Factors influencing the number of technologies and practices used by the farmers in Bean Root Rot management and control in western Uganda: Poisson regression

Dependent variable $=$ Number of technologies and practices used/adopted

\begin{tabular}{lrcl}
\hline Variable name & Coefficient & Robust std error & P-value \\
\hline keep_records & 0.168 & 0.061 & $0.005^{* * *}$ \\
group_member & 0.167 & 0.110 & $\mathbf{0 . 1 2 9}$ \\
get_info_b n & $\mathbf{0 . 1 5 9}$ & $\mathbf{0 . 0 8 1}$ & $\mathbf{0 . 0 4 9} * *$ \\
no_times & $\mathbf{0 . 0 5 5}$ & $\mathbf{0 . 0 1 4}$ & $\mathbf{0 . 0 0 0} * * *$ \\
sex_hh & $\mathbf{- 0 . 0 2 7 8}$ & $\mathbf{0 . 0 7 6}$ & $\mathbf{0 . 7 1 5}$ \\
Inage_hh & $\mathbf{- 0 . 1 9 7}$ & $\mathbf{0 . 1 0 8}$ & $\mathbf{0 . 0 6 7}$ \\
Educhh & $\mathbf{0 . 0 0 1}$ & $\mathbf{0 . 0 0 6}$ & $\mathbf{0 . 8 8 5}$ \\
Hhsize & $\mathbf{- 0 . 0 1 0}$ & $\mathbf{0 . 0 1 0}$ & $\mathbf{0 . 3 2 1}$ \\
Inlandbeans & $\mathbf{0 . 0 1 5}$ & $\mathbf{0 . 0 3 5}$ & $\mathbf{0 . 6 6 7}$ \\
offfarm_work & $\mathbf{0 . 0 6 8}$ & $\mathbf{0 . 0 5 8}$ & $\mathbf{0 . 2 4 4}$ \\
Important & $\mathbf{- 0 . 1 0 4}$ & 0.071 & 0.138 \\
part_sdloan & 0.107 & 0.054 & $0.047^{* *}$ \\
pxnow_imp & 0.0005 & 0.0001 & $0.000^{* * *}$ \\
ConsNWald Chi2 & 1.40813665 .13 & 0.434 & 0.0010 .000 \\
\hline
\end{tabular}

Note; $* * * * *, *$ significant at $1 \%, 5 \%$ and $10 \%$ respectively

(Fig. 3). A combination of methods where farmers practically engaged in the demonstration, coupled with the training sessions, was reported to have enhanced their knowledge and learning. This positively contributed to use of the new technologies and practices disseminated.

Farmers were asked to indicate the advantages and disadvantages, as well as recommendations for improvement for each of dissemination method. Their responses show that demonstrations and FFS were credited for being practical in delivery of new knowledge and skills, which impacted on farmer's ability to understand and apply what was learnt. Overall, farmers reported that the methods used were participatory and they were involved at various stages of implementation. This led to better understanding of the 'how' thereby enhancing adoption of the management package.
Contribution of BRR resistant varieties and management package

A number of local varieties planted significantly reduced since the introduction of improved and BRR resistant varieties in the project area while the quantity of bean seeds planted had significantly increased (Table 7). Similarly, the output harvested per unit area of beans had significantly increased. This increase in quantity harvested and reduction in number of local varieties planted can be attributed to mainly better yields from improved varieties and their resistance to diseases.

Results furthermore show that the average income per season from beans significantly increased (Table 7). The improved varieties fetched higher prices than the local ones; hence, farmers were able to earn more from beans. The improved bean varieties were high yielding, which gave adopting households more 


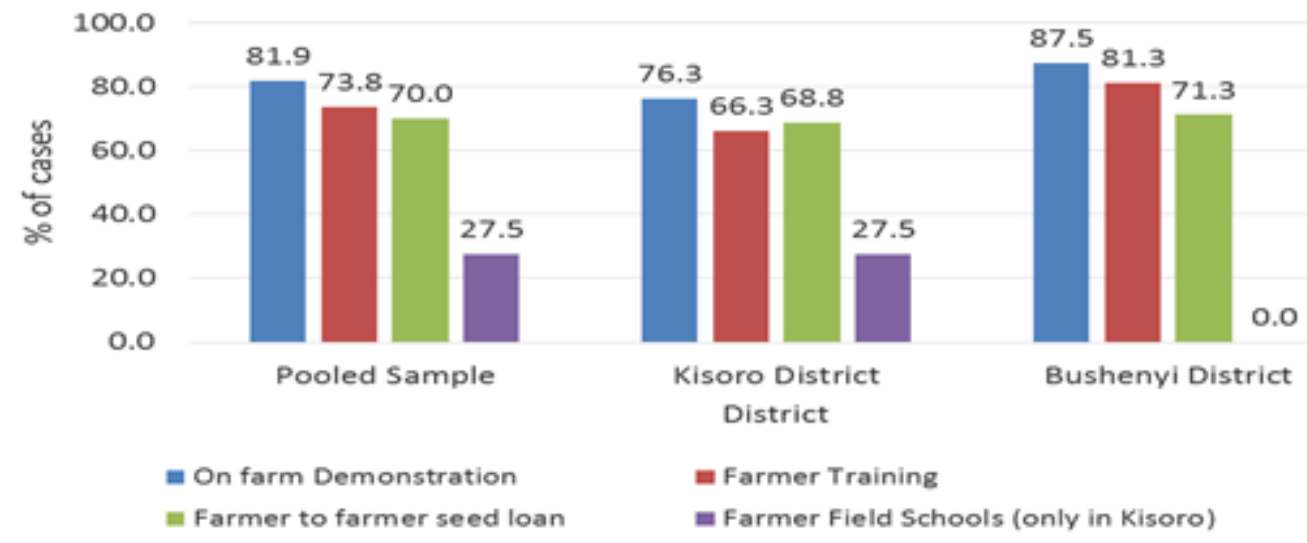

Figure 3. Farmer participation in approaches and methods used in promoting BRR disease management package in south-western Uganda.

marketable surplus. The number of times that farmers reported to consume beans in the household per week also increased significantly over the project period suggesting that farmers were more food secure now.

\section{Discussion}

The observed choice of one seed per hole in Kisoro could also be explained by the fact that farmers in this area mainly grow climbing beans. The increase in number of farmers growing improved varieties between 2003 and 2004 implies that the project played a significant role in enabling farmers to access improved BRR resistant varieties. The observed reduction in number of local cultivars grown shows that that the improved bean varieties were replacing some of the local varieties in the project area, this may have a negative impact on the erosion of genetic diversity for beans.

Farmer consumption needs and market preferences guided the choice in deciding which bean variety to adopt. However, these needs and preferences have also been reported to be very location-specific and some are household-specific. The influence of yield, disease resistance and market demand factors on farmers choice of new varieties is consistent with other adoption studies for improved bean varieties (Mugisha-Mutetika, 1997; Kato, 2000; Nasirumbi, 2008). High yield plays a central role in adoption since it results into adequate consumption amount and also surplus being sold to earn the household income.

Female farmers (women) took a leading role in the adoption decision of improved bean varieties (Table 7). This substantiates previous studies that women play a critical role in bean production and decision making (Kalyebara et al., 2006). Beans are an important food security crop yet food provision is normally a women's responsibility, which perhaps explain why women took a leading role in the decision to continue growing beans. However, recently, men have gained interest in bean production with the introduction of such high yielding bean varieties with highly marketable attributes and associated economic benefits.

The findings that farmers were saving their own seed, and rarely using inorganic 
Table 7. Changes in key outcome variables using the paired t-Test

\begin{tabular}{|c|c|c|c|c|c|c|c|c|c|c|c|c|c|c|c|}
\hline \multirow[t]{3}{*}{ Variable } & \multicolumn{5}{|c|}{ Overall sample } & \multicolumn{5}{|c|}{ Kisoro District } & \multicolumn{5}{|c|}{ Bushenyi District } \\
\hline & \multirow[t]{2}{*}{$\mathrm{N}^{*}$} & \multicolumn{3}{|c|}{ Mean } & \multirow[t]{2}{*}{ p-value } & \multirow[t]{2}{*}{$\mathrm{N}^{*}$} & \multicolumn{3}{|c|}{ Mean } & \multirow[t]{2}{*}{ p-value } & \multirow[t]{2}{*}{$\mathrm{N}^{*}$} & \multicolumn{3}{|c|}{ Mean } & \multirow[t]{2}{*}{$\mathrm{p}$-value } \\
\hline & & Now & Before & Difference & & & Now & Before & Difference & & & Now & Before & Difference & \\
\hline Number of local varieties & 143 & 2.84 & 4.24 & -1.41 & $<0.001$ & 78 & 3.18 & 4.26 & -1.08 & $<0.001$ & 65 & 2.43 & 4.23 & -1.80 & $<0.001$ \\
\hline $\begin{array}{l}\text { Average quanity of seed } \\
\text { planted }(\mathrm{kgs})\end{array}$ & 152 & 26.57 & 22.76 & 3.81 & $<0.001$ & 75 & 37.16 & 30.61 & 6.55 & $<0.001$ & 77 & 16.25 & 15.10 & 1.15 & 0.104 \\
\hline $\begin{array}{l}\text { Average acreage Planted } \\
\text { (acres) }\end{array}$ & 153 & 0.82 & 0.80 & 0.02 & 0.296 & 75 & 0.95 & 0.85 & 0.10 & 0.014 & 78 & 0.68 & 0.75 & -0.06 & 0.879 \\
\hline $\begin{array}{l}\text { Average Bean Yield } \\
\text { (yield in thousands } \\
(1000) \text { of MTs/ha) }\end{array}$ & 151 & 0.28 & 0.17 & 0.11 & $<0.001$ & 74 & 0.36 & 0.22 & 0.14 & $<0.001$ & 77 & 0.20 & 0.11 & 0.09 & $<0.001$ \\
\hline $\begin{array}{l}\text { Number of times beans } \\
\text { were/are eaten per week }\end{array}$ & 159 & 6.19 & 5.59 & 0.60 & $<0.001$ & 79 & 6.75 & 6.28 & 0.47 & 0.001 & 80 & 5.64 & 4.91 & 0.73 & $<0.001$ \\
\hline $\begin{array}{l}\text { Average seasonal income } \\
\text { from bean (In hundred } \\
\text { thousands }(100,000) \text { of } \\
\text { Uganda shillings) }\end{array}$ & 121 & 1.71 & 0.75 & 0.96 & $<0.001$ & 62 & 2.38 & 1.11 & 1.27 & $<0.001$ & 59 & 1.01 & 0.37 & 0.64 & $<0.001$ \\
\hline
\end{tabular}


fertilisers due to high cost and lack of reliable source, imply that input costs and availability had influence on the choice of technology or practice to use in the management of BRR disease. These factors have been identified and discussed by other studies to hinder adoption of new technologies (Venkatesan, 1994; Jones et al., 2007; Nasirumbi, 2008). Community based seed systems have been advocated for as a viable and sustainable way of ensuring that farmers have adequate access and supply of such improved and resistant varieties. This community based model which has shown success in other areas and crops need to be supported to address these challenges.

The positive effect of access to information and number of trainings on adoption of BRR management package increases suggest that both extension and training may be an important source of knowledge for using the technologies and practices. This finding is in agreement with previous research that access to extension is an important factor for enhancing use of agricultural technologies. It enables the farmer to learn and use better production technologies such as improved varieties and recommended management and agronomic practices (Melles, 2003; Nabbumba and Bahigwa, 2005).

The negative and significant relationship between age of the farmer and adoption of integrated management package for BRR disease suggest that younger farmers are more likely to adopt than their older counterparts. The negative relationship could be due to the fact that younger farmers are more easily adaptable to new technologies and practices, as opposed to the older ones, and they also have more time to recoup any fixed cost of adoption. Most studies on adoption have concluded that age and technology adoption are significantly and negatively related (Goodwin and Schroeder, 1994; Dimara and Skuras, 1998; Sevier and Lee, 2004).

The participation dummy showed significant and positive coefficients suggesting that farmer participation in seed loans increased the number of technologies and practices used in the of BRR disease. A study by Nasirumbi (2008) on the adoption of bean production packages in Uganda, observed that farmer-to-farmer seed multiplication as a technology transfer had the least adoption rates. Since farmers received seed free of charge, it created dependency among recipients as they expected to get more seed next season. At times farmers did not attach value on free seed. In addition, most rural farmers had a low capacity to absorb new skills due to low education.

The amount of beans planted and the total bean land by each household seasonally significantly increased. Improved and resistant varieties coupled with proper management practices resulted in increase of bean output per unit area. This is in agreement with other studies by Mafuru et al. (1999) and Ogwal-O (2002) who found out that improved technologies particularly crop varieties increased farm level yields. The increase in output played a great role in household food security, and income as evidenced by increase in number of times beans were consumed in a week and seasonal income from beans. This significantly contributed to the livelihood of the people in the target area.

\section{Conclusion}

Improved varieties, soil amendments option and crop management and agronomic practices were observed to 
control BRR disease. Improved and resistant varieties and farm yard manure were the most widely adopted in the management package for BRR disease. Improved been varieties gradually replaced local bean cultivars as farmers were increasingly appreciating and growing improved and resistant varieties. The main varieties adopted were NABE 12C, NABE 13, and NABE 14. High yield, diseases resistance and palatability were the most important attributes influencing farmers' variety choice. These characteristics need to be continuously considered in the bean breeding programme though the current climatic changes and its associated effects of disease outbreak and drought necessitate breeding for multiple gene resistance.

Since use of resistant varieties and Farm Yard Manure can help reduce the effect of the disease, the communitybased seed production system model which has shown success in other areas and crops need to be promoted to foster sustainable seed supply. Bean farmers in BRR disease susceptible areas should also be encouraged to keep livestock as a sustainable source of manure for enhancing soil fertility. This also calls for the need to support rural enterprises which provide inputs or process agricultural outputs. Establishment of input centres such as stockists will ensure that farmers can access bean seed and other complementary inputs.

Choice of the number of technologies and practices in the management of BRR disease was mainly influenced by access to information, trainings, price of the new variety and participation in technology transfer activities. However, we find that age had a significantly negative influence on the use of the management package. Dissemination of new technologies should be targeted at younger farmers as maximum benefit is likely to be gained from this group than older farmers Since farmer participation in dissemination had a significant influence, it is important that dissemination farmer groupings mix both young and older farmers. This would enhance adoption by older farmers through younger farmer's experience.

To sustain the use of these practices, access to information and extension services in general is a pre-requisite for increased adoption and use of management package. Information on these technologies and practices also need to be disseminated through various Medias i.e. farmer trainings, radio, through institution like churches, farmer groups and schools and development of promotional materials like leaflets and brochures. This will create awareness about available control measures for bean root rot disease and could lead to higher bean impact especially among farmers faced with root rot problem. Information generated from this study is useful to informing breeders of the future breeding strategies and development practitioners on strategic interventions that can improve bean productivity in BRR prone areas.

\section{Acknowledgement}

This study was funded by a grant from the Maendeleo Agricultural Technology Transfer Fund. We thank National Agricultural Research Organisation (NARO) for permitting authors time to conduct this study. We acknowledge the contribution of Dr. Bua Anthony in the entire study, and the enumeration team (Luyima Gabriel and Salongo John Sulume) for their commitment during data collection. 


\section{References}

Abawi, G.S. and Corrales, M.A.P. 1990. Root rots of beans in Latin America and Africa: Diagnosis, research methodologies, and management strategies (No. 35). CIAT.

Greene, W. 2008. Functional forms for the negative binomial model for count data. EconomicsLetters 99:585-590.

Jones, R.B. and Rakotoarisaona, J.J. 2007. Supporting the development of sustainable seed systems for nonhybrid crops. Acta Hort. (ISHS) 752:77-82.

Kalyebara, M.R., Mugisha, K.S., Andima Dymphina and Nasirumbi, L. 2006. The impact of improved bush bean varieties and management technologies in Uganda. Occasional Publication Series. Pan African Bean Research Alliance, CIAT Africa Region, Kampala, Uganda.

Kato, E. 2000. An analysis of factors affecting the adoption of K131 bean variety by women groups in Luuka county, Iganga district, Uganda. Unpublished MSc. Thesis, Makerere University, Kampala, Uganda.

Kornegay, J., Nathan, R., Martínez, G.J.C and Impresión, F.S.A. 1996. The African bean exchange: Patterns of sharing. Cali, Colombia: Centro Internacional de Agricultura Tropical

Mauyo, L.W., Okalebo, J.R., Kirkby, R.A., Buruchara, R., Ugen, M. and Musebe, R.O. 2007. Legal and institutional constraints to KenyaUganda cross-border bean marketing. African Journal of Agricultural Research 2 (11):578-582

Mugisa-Mutetika, M. 1997. Factors influencing adoption and dissemination of new bean cultivars in Uganda. Africa Crop Science Conference Proceedings, Pretoria $13^{\text {th }}-17^{\text {th }}$ January 1997. pp. 1349-1355.

Nasirumbi, L. 2008. Determinants of adoption of improved bean production technologies and practices in Uganda. Unpublished MSc. Thesis, Makerere University, Kampala, Uganda.

Opio, F., Ugen, M.A., Kyamanywa, S., David, S. and Mugisha-Mutetikka, M. 2001. Beans. In: Mukiibi, J.K., Esete, J.P., Musoli, P.C., Oryokot, J.O.E., Twinamasiko, E., Odongkan, O.K., Esegu, J.F.O., Otim-Nape, G.W., Ssali, H. and Odogola, W. (Eds.). Agriculture in Uganda. Volume II Crops. NARO/CTA. Fountain publishers Kampala, Uganda.

Venkatesan, V. 1994. Seed systems in Sub-Saharan Africa: Issues and options. Discussion Paper No. 266. Technical Department, Africa Region. Washington, D.C.: World Bank. 